\title{
The Molecular Genetics of von Willebrand Disease
}

\section{Von Willebrand Hastalığı'nın Moleküler Genetiği}

\author{
Ergül Berber \\ İstanbul Arel University, Department of Molecular Biology and Genetics, İstanbul, Turkey
}

\begin{abstract}
Quantitative and/or qualitative deficiency of von Willebrand factor (vWF) is associated with the most common inherited bleeding disease von Willebrand disease (vWD). vWD is a complex disease with clinical and genetic heterogeneity. Incomplete penetrance and variable expression due to genetic and environmental factors contribute to its complexity. vWD also has a complex molecular pathogenesis. Some vWF gene mutations are associated with the affected vWF biosynthesis and multimerization, whereas others are associated with increased clearance and functional impairment. Moreover, in addition to a particular mutation, type $O$ blood may result in the more severe phenotype. The present review aimed to provide a summary of the current literature on the molecular genetics of $\mathrm{vWD}$.
\end{abstract}

Key Words: Von Willebrand factor, Von Willebrand disease, Von Willebrand factor biosynthesis

Özet

Von Willebrand Faktöründe (vWF) görülen kantitatif azalma veya kalitatif bozukluklar bir kanama diyatezi olan ve oldukça sık rastlanan von Willebrand Hastalığının (VWH) oluşumuna neden olur. VWH klinik ve genetik heterojenite gösteren karmaşık bir hastalıktır. Genetik ve çevresel nedenlere ikincil eksik penetrans ve VWF düzeyinde olan değişiklikler olması VWH'nın karmaşık bir yapı göstermesine neden olan faktörlerdir. VWF genindeki mutasyonlardan bazıları biyosentezi ve multimerizasyonu etkilerken, diğer mutasyonlar vWF'nin dolaşımdan daha erken uzaklaştırılmasına neden olarak fonksiyonunu etkiler. Belirli bir mutasyon ile birlikte kan grubunun da $\mathrm{O}$ olması fenotipin daha ağır olmasına neden olabilir. Bu derlemenin amacı vWH'nın moleküler genetiği ile ilgili güncel yayınları inceleyerek onlarmn bir özetini yapmaktır.

Anahtar Sözcükler: Von Willebrand faktör, Von Willebrand hastalı̆̆ı, Von Willebrand faktör biyosentezi

\section{Introduction}

Von Willebrand disease (vWD) was first described by Erik von Willebrand in a large Aland Islands (Swedish-speaking region of Finland) family in 1924 and was reported to be the most common inherited bleeding disorder in 1926 [1,2]. Its prevalence is estimated to be 0.6\%-1.3\%; however, 1 in 10,000 patients have significant bleeding [3-5]. The characteristic clinical symptoms of vWD affect both males and females, and include mucosal bleeding (including epistaxis), menorrhagia, and prolonged bleeding following trauma or surgery. Severely affected patients may also bleed into soft tissues and joints [6].

vWD is associated with qualitative and quantitative deficiency of von Willebrand factor (vWF). Clinical diagnosis of vWD is based on von Willebrand antigen (vWF:Ag),

Address for Correspondence: Ergül BERBER, PhD,

İstanbul Arel Üniversitesi, Moleküler Biyoloji ve Genetik Bölümü, İstanbul, Turkey

Phone: +902128600480 E-mail: ergulberber@arel.edu.tr

Received/Gelis tarihi : October 14, 2011

Accepted/Kabul tarihi : April 24, 2012 
factor (F) VIII clotting activity (FVIII:C), and von Willebrand ristocetin cofactor activity (vWF:RCo). According to The International Society of Thrombosis and Haemostasis (ISTH), vWD is classified as type 1, type 2, and type 3 (Table 1). Type 1 and type $3 \mathrm{vWD}$ are characterized by partial and complete deficiency of $\mathrm{vWF}$, respectively. Functional deficiency of vWF is characteristic of type 2 $v W D$, which is further classified as $2 \mathrm{~A}, 2 \mathrm{~B}$, and $2 \mathrm{M}$ based on defective interaction with platelets, and as $2 \mathrm{~N}$ based on defective binding to the FVIII molecule. Although ISTH classification of 1994 indicated that $\mathrm{VWD}$ is a disease associated with $v$ WF gene mutations, the 2006 revised ISTH classification states that, "additional genes might influence the biosynthesis and stability of plasma vWF" [7].

Table 1: vWD types,

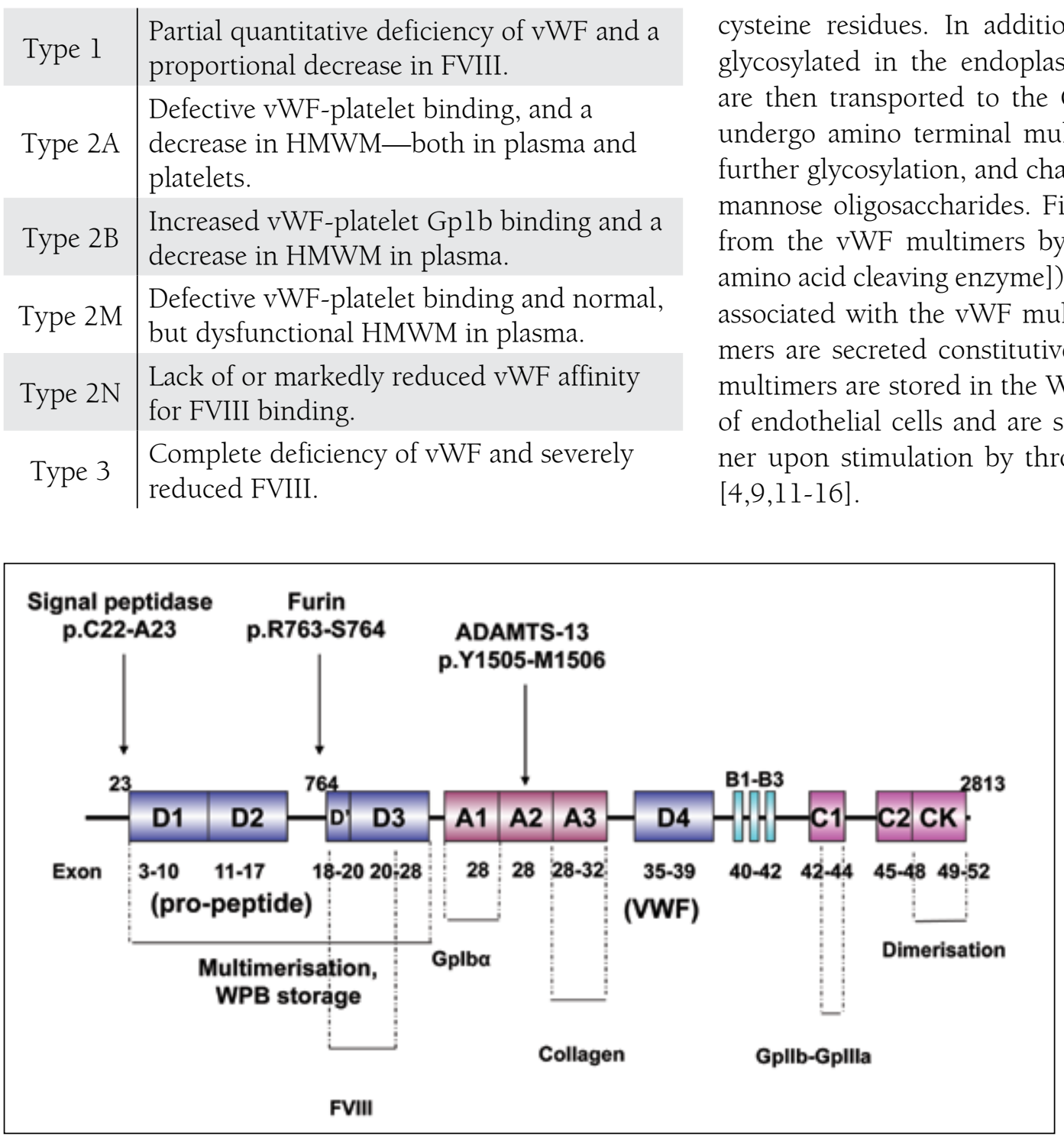

Figure 1: Structure and functional domains of pre-pro-VWF. 
Research has shown that the pro-peptide sequence acts as a chaperone to direct vWF multimers to WPBs [17]. Glycosylation of vWF is an important post-translational modification that protects vWF from proteolytic destruction, affects plasma clearance, and maintains vWF's multimeric structure and interaction with platelets and collagen [18-20]. vWF multimers range in size from a dimer $(\sim 500$ $\mathrm{kDa})$ to ultra large multimers ( $\left.>10 \times 10^{6} \mathrm{kDa}\right)$. vWF multimers released from WPBs are ultra large (UL-vWF) and are the most effective for maintaining hemostasis at the site of injury. Pro-peptide's Cys-X-X-Cys sequence, similar to the active site of protein disulfide isomerases, is thought to be important for vWF multimer formation $[20,21]$.

UL-vWF multimers are proteolytically cleaved by vWF cleaving protease (ADAMTS-13) to physiologically active plasma vWF multimer size within the A2 domain (Y1605-M1606) [22, 23]. The A2 domain serves as a shear sensor and its unfolding is necessary for proteolytic cleavage to expose the cleavage site [24]. In addition to the importance of the cleavage site in the $\mathrm{A} 2$ domain for ADAMTS-13 proteolysis, the residues $\mathrm{C} 1669$ and $\mathrm{Cl670}$ that form a disulfide bond are important for A2 domain folding [25]. Furthermore, studies have shown that polymorphisms in the $\mathrm{Al}$ and $\mathrm{A} 2$ domains affect the efficiency of ADAMTS-13 cleavage [26].

The $v W F$ gene spans a 178-kb genomic region with 52 exons; exon 28 is 1379 bp long and is the largest exon. Exon 28 encodes the domains involved in FVIII binding (D3), platelet binding (A1), collagen binding (A3), and ADAMTS-13 cleavage (A2). There is a highly homologous pseudo-gene containing the $v W F$ gene region from exon 23 to 34 on chromosome 22 (22q11.2) [27,28].

The half-life of vWF in circulation is $12-20 \mathrm{~h}$. The vWF plasma level ranges between $50 \mathrm{IU} / \mathrm{dL}$ and $200 \mathrm{IU} / \mathrm{dL}$ in the general population [29]. Twin studies reported that genetic factors are responsible for $60 \%$ of the variation in the vWF plasma level, which is also affected by a variety of other factors, including age, blood type, stress, thyroid hormone, pregnancy, single-nucleotide polymorphisms (SNPs) in the $v W F$ gene-including the promoter region and other genetic loci [30-33]. Recent studies reported that macrophages are involved in the removal of $\mathrm{vWF} /$ FVIII complex in the liver and spleen, and that D'-D3 domains are implicated in the clearance, although the precise mechanism of vWF clearance remains unknown [3435]. Blood type is a major genetic determinant of the vWF plasma level [30]; it was reported that individuals with type O blood have 25\% less vWF due to increased susceptibility to cleavage by ADAMTS-13 [36].

\section{Type 3 vWD}

Type $3 \mathrm{vWD}$ is characterized by the virtual absence of plasma vWF and a consequent decrease in the FVIII level to $10 \%$. The frequency of type $3 \mathrm{vWD}$ is between 0.5 and 5.3/1,000,000 individuals $[37,38]$. Type $3 v W F$ gene mutations are recessive and such patients are homozygous or compound heterozygous for the $v \mathrm{WF}$ gene mutation that creates a null allele $[39,40]$. Nonsense mutations are the most common of the wide range of type 3 mutations scattered throughout the gene, most of which are in exon 28 (Figure 2). The most common nonsense mutation is R1659X in exon 28 [41]. Nonsense-mediated decay of the allele-specific mRNA is thought to be the molecular mechanism of the nonsense mutations [42].

Missense mutations are the second most common mutations, some of which result in the replacement of cysteine residues that might cause multimerization and secretion defects $[37,43,44]$. Deletions resulting from recombination events include a single exon deletion, multiple exon deletion, and whole gene deletion. The most common deletion in the vWF mutation database is c.2435delC in exon 18. Deletion of exons 4 and 5 is reported to be a recurrent deletion in the UK, and is associated with a

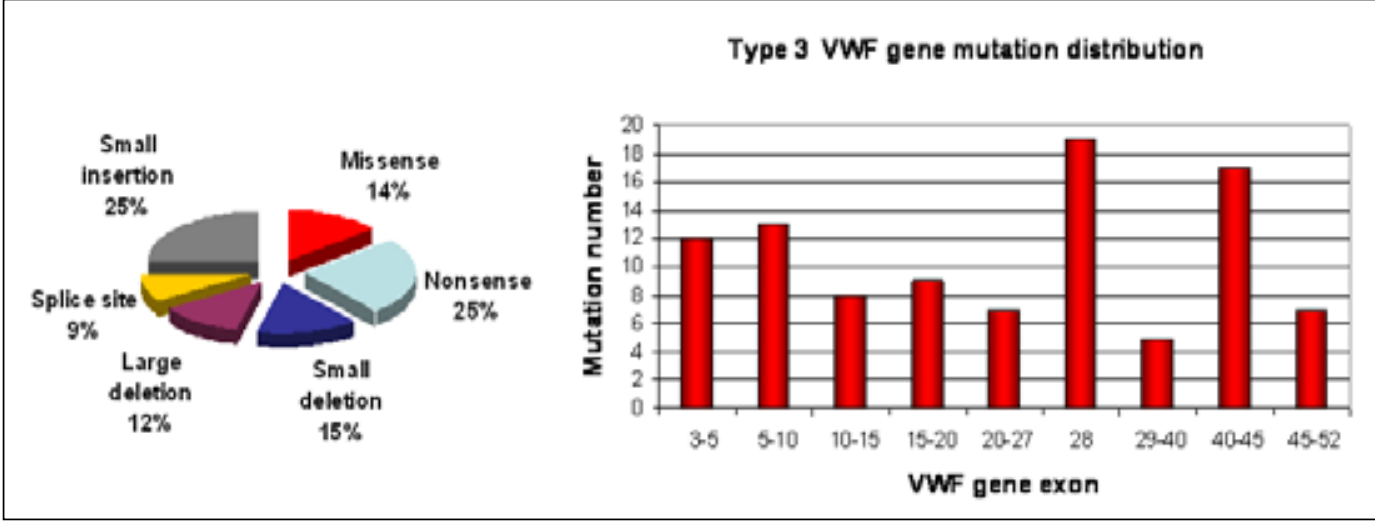

Figure 2: Types and distribution of the VWF gene mutations identified in Type 3 VWD patients $[39,41]$ 
Table 2: vWF gene deletions and inhibitor development.

\begin{tabular}{|l|l|}
\hline Deletion & Inhibitor development \\
\hline Exons 1-3 & No inhibitor \\
\hline Exons 4-5 & No inhibitor \\
\hline Exons 14-52 & Inhibitor \\
\hline Exons 22-43 & Inhibitor \\
\hline Exons 23-52 & Inhibitor \\
\hline Exons 26-34 & No Inhibitor \\
\hline Exons 33-38 & Inhibitor \\
\hline Exon 42 & Inhibitor \\
\hline Exons 1-52 & Inhibitor \\
\hline
\end{tabular}

common haplotype and founder effect [45]. Although it is a rare complication, development of alloantibodies against vWF is observed in association with large deletions and whole gene deletion (Table 2) $[39,46,47]$. Alu (short stretch of DNA)-mediated recombination, impaired secretion, and multimerization are the causative mechanisms for some of the deletions. In addition, gene conversion events between the $v W F$ pseudogene and the $v W F$ gene that result in multiple substitutions and a stop codon in the $v W F$ gene are reported to be a common pathogenic mechanism in type $3 \mathrm{vWD}$ patients $[48,49]$.

\section{Type 2 vWD}

There is a functional deficiency of vWF in patients with type $2 \mathrm{vWD}$, which is further classified as $2 \mathrm{~A}, 2 \mathrm{~B}$, and $2 \mathrm{M}$ based on defective interaction with platelets, and as $2 \mathrm{~N}$ based on defective binding to the FVIII molecule.

\section{Type 2A vWD}

Type $2 \mathrm{~A} \mathrm{vWD}$ is characterized by defective platelet binding due to the absence of high molecular weight vWF
(HMW-vWF) multimers in both plasma and platelets. Type 2A vWD patients have a low vWF:RCo to vWF:Ag ratio $(<0.6)$ [37]. Type $2 \mathrm{~A}$ mutations include missense, deletion, insertion, and frameshift mutations; $73 \%$ of these mutations are located within exon 28 (Figure 3) and $90 \%$ of these mutations are missense mutations that are either recessive or dominant [40]. D2 domain mutations are recessive and prevent multimer formation; patients are either homozygous or compound heterozygous with a null allele. Mutations in the D3, A2, A1, and CK domains are dominant mutations. D3 and CK mutations inhibit multimerization and dimerization, respectively [50,51]. A2 and A1 mutations result in an increase in susceptibility to ADAMTS-13 proteolysis, defective biosynthesis, or intracellular retention $[52,53]$. Type $2 \mathrm{~A}$ vWD mutations that cause defective biosynthesis, intracellular storage, and intracellular retention (e.g. N528S) are group I mutations [54-56]; other mutations that increase ADAMTS-13 sensitivity are group II mutations (e.g. L1505R) [57]. Group I mutations result in a more severe phenotype than do group II mutations and patients respond better to DDAVP treatment [58].

\section{Type 2B vWD}

Spontaneous and increased binding of vWF to GpIb $\alpha$ receptors on platelets due to dominant gain-of-function $\mathrm{Al}$ domain mutations and the absence of HMW-vWF multimers in plasma are characteristic of type $2 \mathrm{~B} v W D$. Due to spontaneous platelet binding HMW-vWF multimers in plasma are proteolyzed by ADAMTS-13 [7,59]. Patients have a low VWF:RCo to VWF:Ag ratio $(<0.6)$ and an increase in ristocetin-induced platelet aggregation (RIPA) at low dose ristocetin $[37,60]$. Thrombocytopenia is also observed in some type 2B vWD patients under stress conditions, such as pregnancy or infection, and after DDAVP use. Patients may have giant platelets and also suffer from

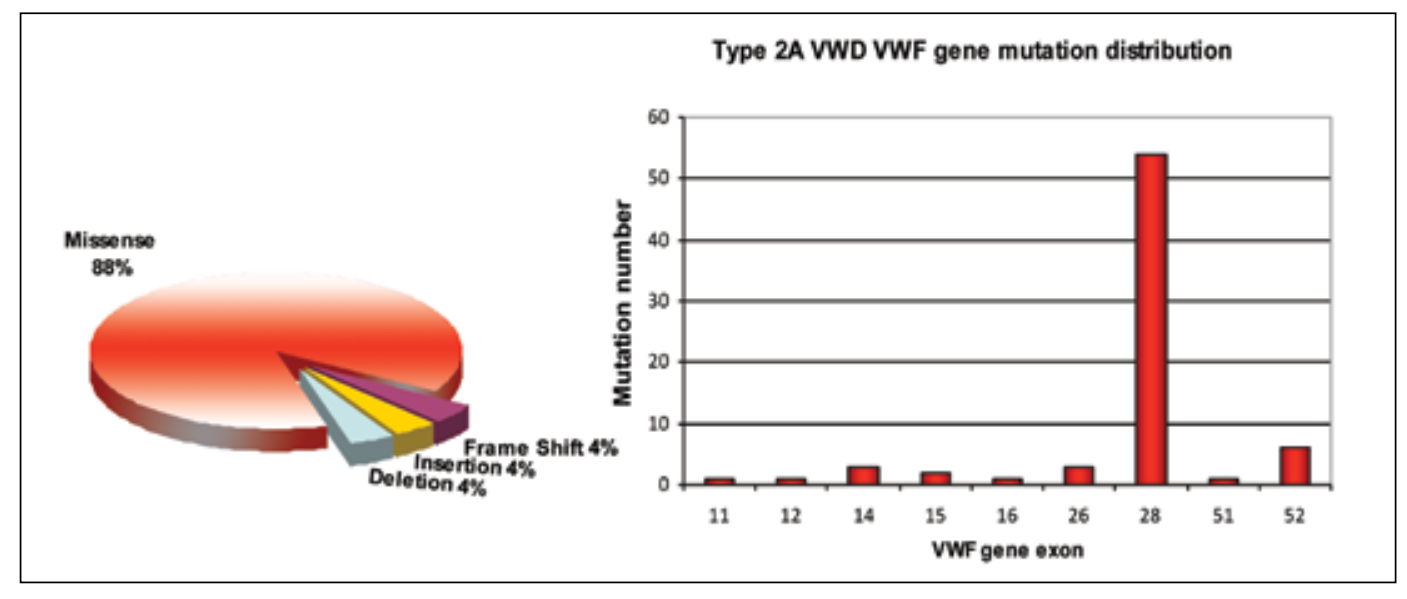

Figure 3: Types and distribution of the VWF gene mutations identified in Type 2A VWD patients $[39,41]$ 

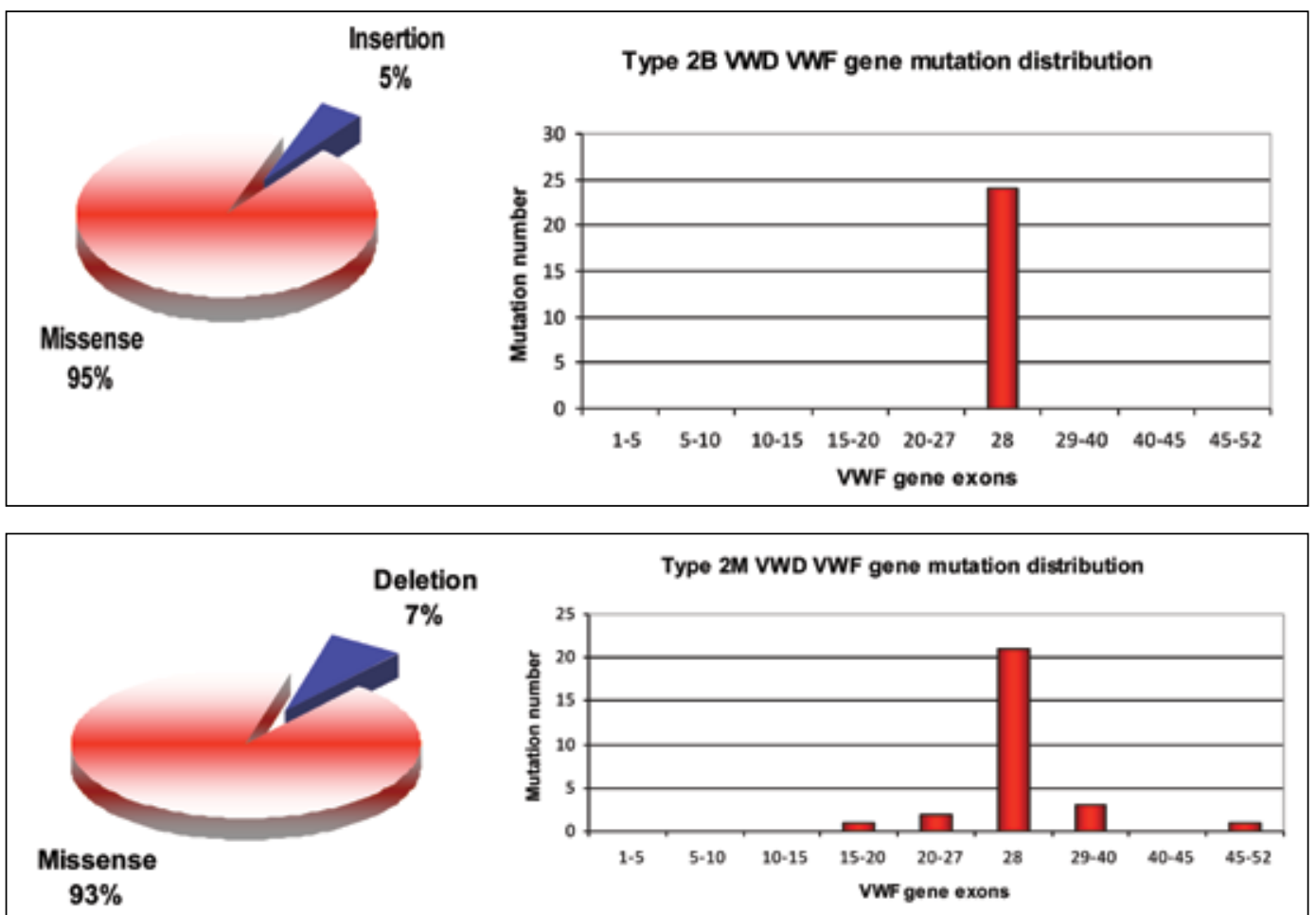

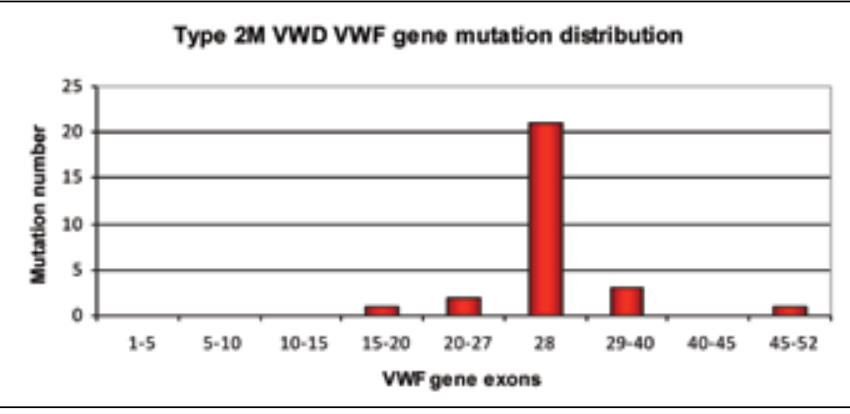

Figure 4: Types and distribution of the VWF gene mutations identified in Type 2B VWD patients $[39,41]$
Figure 5: Types and distribution of the VWF gene mutations identified in Type 2M VWD patients $[39,41]$ spontaneous platelet agglutination [61-65]. Clinical manifestation of type 2B vWD varies and patients with thrombocytopenia have the most severe phenotype [66]. Furthermore, mouse models of type 2B mutations R2306Q and V1316M show that both mutations and ADAMTS-13 determine the phenotype [59].

There are $>50$ type $2 \mathrm{~B}$ mutation submissions in the vWF mutation database. Type 2B mutations are highly penetrant and are detected only between codons 1266 and 1461-the region of exon 28 of the $v W F$ gene encoding Al domain; 96\% of these mutations are missense mutations, most of which are observed at mutation hotspot arginine codons at positions 1306 (R1306W/Q/L), 1308 (R1308C/P), and 1341 (R1341Q/P/L) (Figure 4) [41]. A recent type $2 \mathrm{~B}$ genotype-phenotype study reported that V1316M mutation is associated with the most severe bleeding score, as compared to other type $2 \mathrm{~B}$ mutations $[66,67]$. Moreover, some type $2 \mathrm{~B}$ mutations are associated with dynamic changes in the vWF level in association with the platelet count. For example, it was reported that a patient with R1306W mutation had normalized high molecular weight multimers (HMWM), but severe thrombocytopenia and a decrease in HMWM after correction of the platelet count [68]. In contrast to classical type 2B mutations, P1266Q/L (New York/Malmö) and R1308L mutations do not affect multimer size and do not cause thrombocytopenia [66].

\section{Type 2M vWD}

Type $2 \mathrm{M} v W D$ is characterized by a defect in vWFplatelet binding due to dysfunctional HMW-vWF caused by $v W F$ gene mutations, despite a quantitatively normal vWF multimeric structure. Type $2 \mathrm{M}$ mutations are dominant loss-of-function mutations predominantly located within the platelet GPlb binding Al domain [7,37]; 93\% of these mutations are missense mutations and the remainder are small in-frame deletions [41]. Type 2M mutations are fully penetrant and $75 \%$ occur in exon 28 of the $v W F$ gene (Figure 5). A Canadian cohort study reported that a vWF:RCo to vWF:Ag ratio $<0.4$ in type $2 \mathrm{M}$ vWD patients was strongly associated with Al domain mutations [69]. There are also a small number of mutations in the A3 domain (S1731T, W1745C, and S1738A) that affect collagen attachment and cause mild bleeding. Despite the fact that type $2 \mathrm{M} v \mathrm{vWD}$ patients respond poorly to DDAVP treatment, patients with A3 domain mutations respond well to DDAVP $[70,71]$.

\section{Type 2N vWD}

Type $2 \mathrm{~N} v W D$ is characterized by markedly reduced or lack of vWF affinity FVIII binding. Recessive mutations in the vWF-FVIII binding domain result in the lack of FVIII binding and a disproportionate decrease in the FVIII:C level to between 0.05 and $0.30 \mathrm{IU} / \mathrm{mL}$. The type $2 \mathrm{~N} v W D$ phenotype is observed in patients that are homo- 
zygous for the same FVIII binding mutation, compound heterozygous for 2 different FVIII binding mutations, or compound heterozygous for a FVIII binding mutation and a vWF null allele [37,72-74]. vWF binds to FVIII through its D' domain and part of the D3 domain between residues Ser764 and Arg1035 encoded by exons 18-23 in the $v W F$ gene [75]; however, mutations beyond the FVIII binding regions (from exon 23 to 27) are also associated with decreased FVIII binding (e.g., Q1053H and C1060R) $[76,77]$.

In addition to FVIII binding impairment, type $2 \mathrm{~N}$ mutations might also cause secretion and multimerization defects, especially cysteine mutations (C788R/Y, Y795C, and C804F) [78]. Moreover, the 2 pro-peptide mutations R760C and R763G sterically inhibit FVIII binding by preventing furin cleavage of pro-peptide, resulting in the formation of UL-vWF multimers [37,74]. Type $2 \mathrm{~N}$ mutations occur primarily between exon 18 and 20 [41]; $95 \%$ of the mutations are missense mutations (Figure 6). R816W and R854Q are the most common type $2 \mathrm{~N}$ mutations. Type $2 \mathrm{~N}$ mutations are highly penetrant and the level of FVIII in type $2 \mathrm{~N}$ vWD patients is associated with the specific mutation. For example, R816W mutation leads to a severe decrease in the FVIII level $(<10 \mathrm{IU} / \mathrm{mL})$ and patients do not respond to DDAVP, whereas R854Q mutation is associated with a less severe phenotype and a FVIII level of $20 \mathrm{IU} / \mathrm{mL}$, and such patients do respond to DDAVP [78].

\section{Type 1 vWD}

Type $1 \mathrm{vWD}$ is characterized by partial quantitative deficiency of functionally normal vWF. The level of vWF is reduced to between 5 and $50 \mathrm{IU} / \mathrm{dL}$, without significant abnormalities in multimer structure [5]. It is generally inherited as autosomal dominant; however, its clinical diagnosis is complicated due to incomplete penetrance and variable expression of the $v W F$ gene [79]. In addition, compound heterozygosity for type 3 or type $2 \mathrm{~N}$ mutations influence the severity of the disease. Recent studies performed in the European Union, the UK, and Canada have provided some data on the molecular pathology of type $1 \mathrm{vWD}$ and established that there is a genotype-phenotype correlation [80-82]; the vWF gene was analyzed in 300 type $1 \mathrm{vWD}$ patients in the 3 studies, which demonstrated that both allelic and locus heterogeneity should be considered to play a role in the molecular pathogenesis of type $1 \mathrm{vWD}$.

Many candidate mutations, including promoter, splice site, nonsense, missense, and small insertions, as well as deletions have been identified; $80 \%$ of the mutations
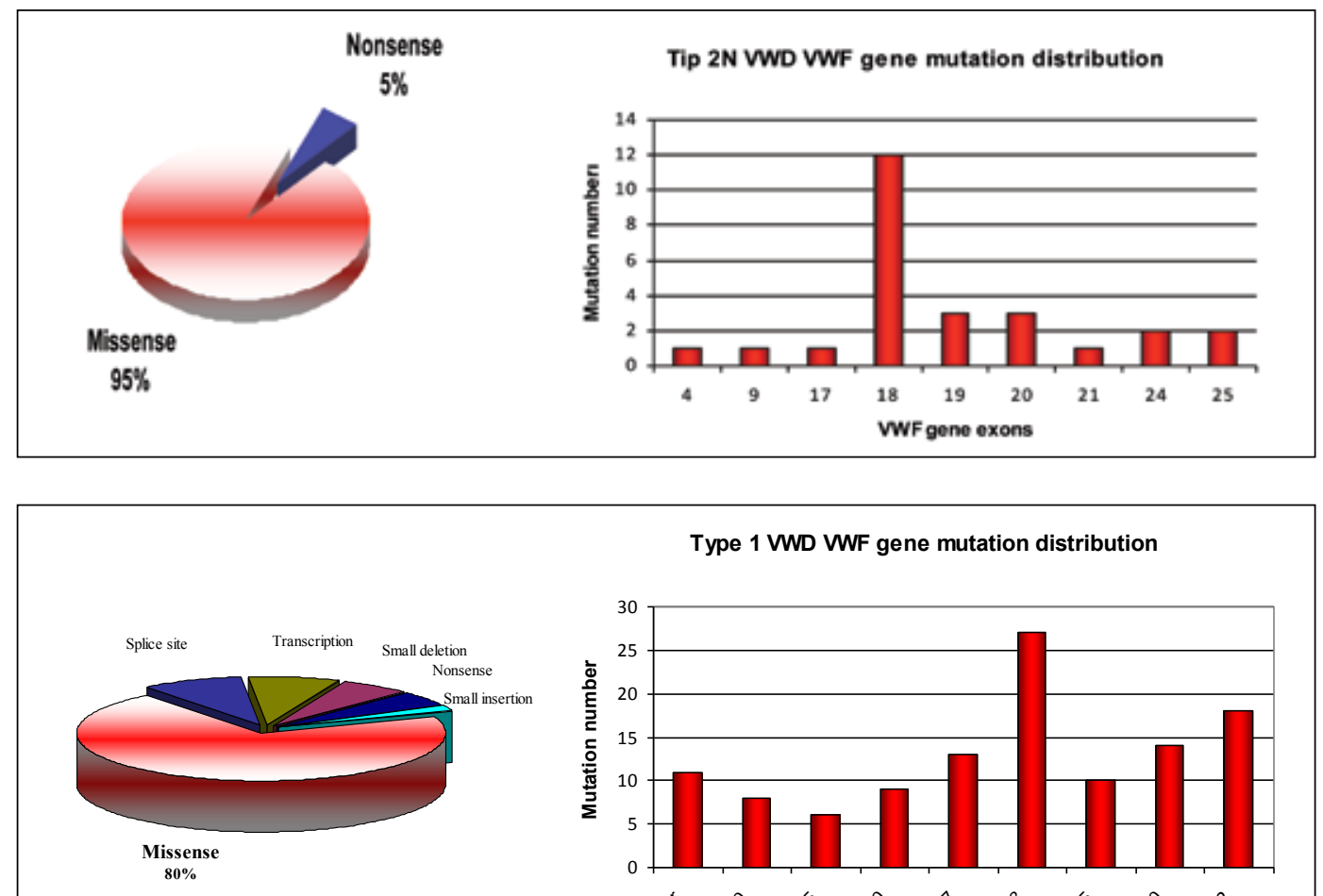

Type 1 WWD WWF gene mutation distribution

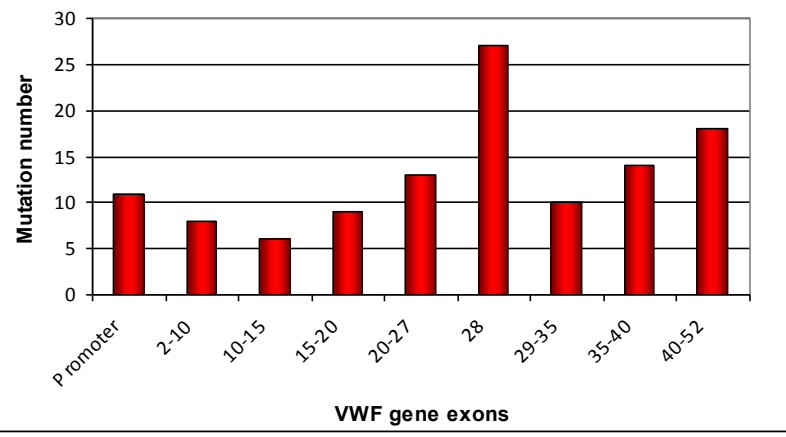

Figure 6: Types and distribution of the VWF gene mutations identified in Type $2 \mathrm{~N}$ VWD patients $[39,41]$

Figure 7: Types and distribution of the VWF gene mutations identified in Type 1 VWD patients $[39,41]$ 
are missense mutations and mutations primarily occur in exon 28 (Figure 7). In addition, some patients have more than $v W F$ gene mutations. One of the major findings of these studies is that type $1 \mathrm{vWD}$ is not always related to $v W F$ gene mutations. Candidate mutations were identified only in $65 \%$ of patients and are more likely in patients with vWF:Ag <30 IU/dL. Moreover, mutation penetrance increases as the vWF plasma level decreases $[37,81]$. Type O blood type is associated with type $1 \mathrm{vWD}$ in patients lacking any identified $v W F$ gene mutation $[39,81]$. Studies that examined expression of the candidate mutations noted 2 primary pathogenetic mechanisms in type $1 \mathrm{vWD}$. The first mechanism is intracellular retention of the mutant $v W F$ gene. Some $v W F$ gene mutations, such as C1149R, were shown to dominantly impair vWF secretion $[83,84]$. Type 1 mutations that cause a loss or increase in cysteine residue (C2257S or G2441C) affect biosynthesis by causing significant intracellular retention and loss of multimeric structure. In contrast to this, D4 domain mutation L2207P caused similar significant intracellular retention and multimer loss to the mutations that involve Cys residue [85].

The second pathogenic mechanism is accelerated vWF clearance, which causes a very brief response to DDAVP in patients $(<4 \mathrm{~h})$, as compared to healthy individuals (6-9 $\mathrm{h}$ ), and an increase in the vWF pro-peptide (vWFpp) to vWF:Ag ratio. Due to the clearance this type of vWD is also known as type $1 \mathrm{C} v W D$. The mutations associated with accelerated vWF clearance are R1205H (vWD Vicenza), C1130G/F/R, W1144G, I1416N, and S1279F [5,86-88].

Research has shown that ABO blood types also influence vWF clearance and the severity of the phenotype in $v W F$ gene mutation carriers. For example, Y1584C mutation was the most common type 1 vWD mutation in 3 type 1 studies with incomplete penetrance. Although this mutation causes intracellular retention, all symptomatic Y1584C carriers also had type O blood in the Canadian and UK type $1 \mathrm{vWD}$ studies, and patients in the UK study had an elevated vWFpp to vWF:Ag ratio [89-92]. Similarly, C2362F carriers with type O blood had a more severe phenotype [93].

There are also some common type 1 vWD mutations for which the molecular pathogenesis has yet to be discerned. For example, R924Q is a recurrent mutation associated with a founder haplotype and marks a splicing defect that created a null allele in a Canadian patient that was a compound heterozygous for R816W type $2 \mathrm{~N}$ mutation; however, other studies reported that R924Q variation is a polymorphism $[94,95]$.

\section{Genetic testing in vWD}

Genetic testing of patients with inherited diseases has an important role in expanding our understanding of the molecular pathology of such diseases, and in decreasing disease-related morbidity and mortality. For some inherited complex disorders, including maturity onset diabetes of the young (MODY), genetic testing is important for differentiating disease subtypes and determining the optimal treatment method. Moreover, prenatal genetic diagnosis is extremely important for decreasing the frequency of inherited diseases as well as limiting the psychological and economic consequences for patients and their families.

vWD is a complex inherited bleeding disorder with clinical and genetic heterogeneity. Incomplete penetrance and variable expression are the major roadblocks to clinical diagnosis. Clinical diagnosis of vWD is based on phenotypic data; however, high variation in assays or lower detection limit, particularly vWF:RCo, and unavailability of certain tests like vWF:FVIIIB (vWF:FVIII bonding assay) or multimer analysis would also lead to misdiagnosis or inefficient diagnosis of vWD. Genetic testing of patients with vWD is based on $v W F$ gene analysis. The value of genetic testing in vWD depends on the subtype; it is useful for the differential diagnosis and determining the proper treatment in patients with type $2 \mathrm{vWD}$. Genetic testing could be helpful in differentiating type $2 \mathrm{~N}$ vWD from hemophilia $\mathrm{A}$, which is possible by analyzing the exons encoding the FVIII binding region (exons 17-25). Genetic testing could also be useful for differentiating type 2B vWD from platelet-type-vWD, which is based on analyzing just exon 28 in the $v W F$ gene. In addition, genetic testing is important for the correct diagnosis of type $2 \mathrm{~A}$ and type $2 \mathrm{M}$ vWD if multimer analysis cannot be performed. Genetic diagnosis of type 2A and type 2M vWD could also benefit the treatment of $\mathrm{vWD}$, as type $2 \mathrm{~A}$ patients respond to DDAVP, whereas type $2 \mathrm{M}$ patients do not. Clinical diagnosis of type $3 \mathrm{vWD}$ is easily made based on phenotypic testing, as vWF is completely absent in the plasma. Nevertheless, genetic testing of type $3 \mathrm{vWD}$ patients could be used for genetic counseling, prenatal diagnosis, and predicting inhibitor formation; however, the whole gene must be analyzed because mutations are scattered along the $v W F$ gene.

On the other hand, because correctly diagnosing type 1 vWD is clinically problematic and due to partial deficiency of vWF, molecular diagnosis is also problematic because of the complexity and mutational heterogeneity of the $v W F$ gene. Many candidate mutations have been identified in type $1 \mathrm{vWD}$ patients; in vitro expression studies are important for determining whether or not they are patho- 
genic variations. Hence, expression analysis of some candidate mutations showed they are just neutral polymorphisms. For some sequence variations, such as R924Q, the presence of a specific haplotype might be responsible for the disease phenotype. Moreover, it is likely that $\geq 35 \%$ of type $1 \mathrm{vWD}$ patients do not have any $v W F$ gene mutation. Finally, the presence of incomplete penetrance and the complex pathogenesis of $\mathrm{vWD}$ are major limitations to making a genotype-phenotype association in type $1 \mathrm{vWD}$ patients. Consequently, although the use of genetic testing in type $1 \mathrm{vWD}$ is of limited use, it could be used in patients with vWF:Ag $<30 \%$ and in those with mutations that affect vWF clearance, such as R1205H mutation, for differentiating type 1 vWD from type 2 vWD [96-98].

\section{Conclusion}

vWD is an inherited bleeding disorder with a complex molecular pathology. Although numerous studies in various geographic regions have considerably advanced our understanding of the molecular mechanism of $\mathrm{vWD}$, cases of $\mathrm{vWD}$ not associated with $v \mathrm{WF}$ gene defects are still observed. Complete understanding of the molecular pathogenesis of vWD requires additional in vitro expression studies that observe the effects of the candidate $v W F$ gene mutations. In addition, use of whole genome or exome (part of genome formed by exons) sequencing (novel technologies) might identify other genetic determinants of vWD and help to complete our understanding of vWD by demonstrating the genotype-phenotype relationship.

\section{Conflict of Interest Statement}

The authors of this paper have no conflicts of interest, including specific financial interests, relationships, and/ or affiliations relevant to the subject matter or materials included.

\section{References}

1. Lillicrap D. Genotype/phenotype association in von Willebrand disease: Is the glass half ful lor empty? J Thromb and Haemost 2009; 7:65-70.

2. Von Willebrand EA. Finska Lakarasallsk Hand 1926; 68:87.

3. Rodeghiero F, Castaman G, Dini E. Epidemiological investigation of the prevalence of von Willebrand's disease. Blood 1987; 69:454-459.

4. Werner EJ, Broxson EH, Tucker EL, Giroux DS, Shults J, Abshire TC. Prevalence of von Willebrand disease in children: a multiethnic study. J Pediatr 1993; 123:893-898.
5. Bloom AL. von Willebrand factor: Clinical features of inherited and acquired disorders. Mayo Clin Proc 1991; 66:743-751.

6. Rodeghiero F, Castaman G, Tosetto A. Optimizing treatment of von Willebrand disease by using phenotypic and molecular data. Hematology Am Soc Hematol Educ Program 2009; 113-123.

7. Sadler JE, Budde U, Eikenboom JC, Favaloro EJ, Hill FG, Holmberg L, Ingerslev J, Lee CA, Lillicrap D, Mannucci PM, Mazurier C, Meyer D, Nichols WL, Nishino M, Peake IR, Rodeghiero F, Schneppenheim R, Ruggeri ZM, Srivastava A, Montgomery RR, Federici AB. Update on the pathophysiology and classification of von Willebrand disease: A report of the Subcommittee on von Willebrand Factor. J Thromb Haemost 2006; 4:2103-2114.

8. Ruggeri ZM. Structure of von Willebrand factor and its function in platelet adhesion and thrombus formation. Best Pract Res Clin Haematol 2001; 14:257-279.

9. Wagner DD. Cell Biology of Von Willebrand factor. Annu Rev Cell Biol. 1990; 6:217-246.

10. Sadler JE. Von Willebrand factor assembly and secretion. J Thromb Haemost 2009; 7:24-27.

11. Verweij CL, Diergaarde PJ, Hart M, Pannekoek H. Fulllength von Willebrand factor (vWF) encodes a highly repetitive protein considerably larger than the mature $\mathrm{vWF}$ subunit. EMBO J 1986; 5:1839-1846.

12. Lowenstein CJ, Morrell CN, Yamakuchi M. Regulation of Weibel-Palade body exocytosis. Trends Cardiovasc Med 2005; 15:302-308.

13. Rondaij MG, Bierings R, Kragt A, van Mourik JA, Voorberg J. Arterioscler Dynamics and plasticity of Weibel-Palade Bodies in endothelial cells. Arterioscler Thromb Vasc Biol 2006; 26:1002-1007.

14. Giblin JP, Hewlett LJ, Hannah MJ. Basal secretion of von Willebrand factor from human endothelial cells. Blood 2008; 112:957-964.

15. Bonthron DT, Handin RI, Kaufman RJ, Wasley LC, Orr EC, Mitsock LM, Ewenstein B, Loscalzo J, Ginsburg D, Orkin $\mathrm{SH}$. Structure of pre-pro von Willebrand factor and its expression in heterologous cells. Nature 1986; 324:270273.

16. Wang JW, Eikenboom J. Von Willebrand disease and Weibel-Palade bodies. Hamostaseologie 2010; 30:150-155.

17. Haberichter SL, Jacobi P, Montgomery RR. Critical independent regions in the VWF propeptide and mature VWF that enable normal VWF storage. Blood 2003; 101:1384-1391.

18. Titani K, Kumar S, Takio K, Ericsson LH, Wade RD, Ashida K, Walsh KA, Chopek MW, Sadler JE, Fujikawa $\mathrm{K}$. Amino acid sequence of human von Willebrand factor. Biochemistry 1986; 25:3171-3184. 
19. Millar CM, Brown SA. Oligosaccharide structures of von Willebrand factor and their potential role in von Willebrand disease. Blood Rev 2006; 20:83-92.

20. Matsui T, Titani K, Mizuochi T. Structures of the asparagines-linked oligosaccharide chains of human von Willebrand factor. Occurrence of blood group A, B, and $\mathrm{H}(\mathrm{O})$ structures. J Biol Chem 1992; 267:8723-8731.

21. Allen S, Abuzenadah AM, Hinks J, Blagg JL, Gursel T, Ingerslev J, Goodeve AC, Peake IR, Daly ME. A novel von Willebrand disease-causing mutation (Arg273Trp) in the von Willebrand factor propeptide that results in defective multimerization and secretion. Blood 2000; 96:560-568.

22. Fujikawa K, Suzuki H, McMullen B, Chung D. Purification of human von Willebrand factor-cleaving protease and its identification as a new member of the metalloprotease family. Blood 2001; 98:1662-1666.

23. Dent JA, Berkowitz SD, Ware J, Kasper CK, Ruggeri ZM. Identification of a cleavage site directing the immunochemical detection of molecular abnormalities in type IIA von Willebrand factor. Proc Natl Acad Sci USA 1990; 87:6306-6310.

24. Zhang Q, Zhou YF, Zhang CZ, Zhang X, Lu C, Springer TA. Structural specializations of A2, a force-sensing domain in the ultralarge vascular protein von Willebrand factor. Proc Natl Acad Sci USA 2009; 106:9226-9231.

25. Luken BM, Winn LNY, Emsley J, Lane DA, Crawley JTB. The importance of vicinal cysteines, C1669 and C1670, for von Willebrand factor A2 domain function. Blood 2010; 115:4910-4913.

26. Pruss CM, Notley CRP, Hegadorn CA, O'Brien L, Lillicrap D. ADAMTS13 cleavage efficiency is altered by mutagenic and to a lesser extent, polymorphic sequence changes in the A1 and A2 domains of von Willebrand factor. Br J Haematol 2008; 143:552-558.

27. Mancuso DJ, Tuley EA, Westfield LA, Worrall NK, SheltonInloes BB, Sorace JM, Alevy YG, Sadler JE. Structure of the gene for human von Willebrand factor. J Biol Chem 1989; 264:19514-19527.

28. Mancuso DJ, Tuley EA, Westfield LA, Lester-Mancuso TL, Le Beau MM, Sorace JM, Sadler JE. Human von Willebrand factor gene and pseudogene: structural analysis and differentiation by polymerase chain reaction. Biochemistry 1991; 30:253-269.

29. Sadler JE, Mannucci PM, Berntorp E, Bochkov N, Boulyjenkov V, Ginsburg D, Meyer D, Peake I, Rodeghiero F, Srivastava A. Impact, diagnosis and treatment of von Willebrand disease. Thromb Haemost 2000; 84:160-174.

30. Orstavik KH, Magnus P, Reisner H, Berg K, Graham JB, Nance W. FVIII and factor IX in a twin population: Evidence for a major effect of ABO locus on FVIII level. Am J Hum Genet 1985; 37:89-101.
31. Gill JC, Endres-Brooks J, Bauer PJ, Marks WJ Jr, Montgomery RR. The effect of ABO blood group on the diagnosis of von Willebrand disease. Blood 1987; 69:1691-1695.

32. Miller CH, Dilley A, Richardson L, Hooper WC, Evatt BL. Population differences in von Willebrand factor levels affect the diagnosis of von Willebranddisease in African-American women. Am J Hematol 2001; 67:125-129.

33. Bloom AL. Von Willebrand factor: Clinical features of inherited and acquired disorders. Mayo Clin Proc. 1991; 66:743-751.

34. Lenting PJ, Westein E, Terraube V, Ribba AS, Huizinga EG, Meyer D, de Groot PG, Denis CV. An experimental model to study in vivo survibal of von Willebrand factor. J Biol Chem 2004; 279:13:12102-12109.

35. van Schooten CJ, Shahbazi S, Groot E, Oortwijn BD, van den Berg HM, Denis CV, Lenting PJ. Macrophages contribute to the cellular uptake of von Willebrand factor and factor VIII in vivo. Blood 2008; 112:1704-1712.

36. Bowen DJ, Collins PW. Insights into von Willebrand factor proteolysis: Clinical implications. Br J Haematol 2006; 133:457-467.

37. Lillicrap D. Von Willebrand disease-Phenotype versus genotype: Deficiency versus disease. Thromb Res 2007; 120:S11-S16.

38. Lak M, Peyvandi F, Manucci PM. Clinical manifestations and complications of childbirth and replacement therapy in 385 Iranian patients with type 3 VWD. Br J Haematol 2000; 111:1236-1239.

39. Goodeve AC. The genetic basis of von Willebrand disease. Blood Rev 2010; 24:123-134.

40. Castaman G, Bertoncello K, Bernardi M, Eikenboom JCJ, Budde U, Rodeghiero F. Autosomal recessive von Willebrand Disease Associated With Compound Heterozygosity for a Novel Nonsense Mutation (2908 Del C) and the Missense Mutation C2362F: Definite Evidence for the Non-Penetrance of the C2362F Mutation. Am J Hematol. 2007; 82:376-380.

41. ISTH-SSC VWF Online Database [homepage on the internet] (C2007 The University of Sheffield [Updated 2010 August 07: cited October 2010] Available from: http://vWF. group.shef.ac.uk/

42. Castaman G, Plate M, Giacomelli SH, Rodeghiero F, Duga S. Alterations of mRNA processing and stability as a pathogenic mechanism in von Willebrand factor quantitative deficiencies. J Thromb Haemost 2010; 8:2736-2742.

43. Baronciani L, Cozzi G, Canciani MT, Peyvandi F, Srivastava A, Federici AB, Manucci PM. Molecular defects in type 3 von Willebrand disease: Updated results from 40 multiethnic patients. Blood Cells Mol Dis 2003; 30:264-270.

44. Sutherland MS, Keeney S, Bolton-Maggs PHB, Hay CRM, Will A, Cumming AM. The mutation spectrum associated with type 3 von Willebrand disease in a cohort of patients from North West of England. Haemophilia 2009; 15:10481057. 
45. Sutherland MS, Cumming AM, Bowman M, Bolton-Maggs PH, Bowen DJ, Collins PW, Hay CR, Will AM, Keeney S. A novel deletion mutation is recurrent in von Willebrand disease types 1 and 3. Blood 2009; 114:1091-1098.

46. Mohl A, Boda Z, Jager R, Losonczy H, Marosi A, Masszi T, Nagy E, Nemes L, Obser T, Oyen F, Radványi G, Schlammadinger Á, Szélessy ZS, Várkonyi A, Vezendy K, Vilimi B, Schneppenheim R, Bodó I. Common large partial VWF gene deletion does not cause alloantibody formation in the Hungarian type 3 von Willebrand disease population. J Thromb Haemost 2011; 9:945-952.

47. Federici AB. Clinical and molecular markers of inherited VWD type 3: Are deletions of the VWF gene associated with alloantibodies to VWF?. J Thromb Haemost 2008; 6:17261728.

48. Gupta PK, Adamtziki E, Budde U, Jaiprakash M, Kumar H, Harbeck-Seu A, Kannan M, Oyen F, Obser T, Wedekind I, Saxena R, Schneppenheim R. Gene conversions are a common cause of von Willebrand disease. Br J Haematol 2005; 130:752-758.

49. Eikenboom JC, Vink T, Briët E, Sixma JJ, Reitsma PH, Multiple substitutions in the von Willebrand factor gene that mimic the pseudogene sequence. Proc Natl Acad Sci USA 1994; 91:2221-2224.

50. Hommais A, Stepanian A, Fressinaud E, Mazurier C, Meyer D, Girma JP, Ribba AS. Mutations C1157F and C1234W of von Willebrand factor cause intracellular retention with defective multimerization and secretion. J Thomb Haemost 2006; 4:148-157.

51. Hommais A, Stepanian A, Fressinaud E, Mazurier C, Pouymayou K, Meyer D, Girma JP, Ribba AS. Impaired dimerizattion of von Willebrand factor subunit due to mutation A2801D in the CK domain results in a recessive type 2A subtype IID von Willebrand disease. Thromb Haemost 2006; 95:776-781.

52. Lyons SE, Bruck ME, Bowie EJW, Ginsburg D. Impaired intracellular transport produced by a subset of type IIA von Willebrand disease mutations. J Biol Chem. 1992; 267:4424-4430.

53. O'Brien LA, Sutherland JJ, Weaver DF, Lillicrap D. Theoretical structural explanation for group I and group II, type $2 \mathrm{~A}$ von Willebrand disease mutations. J Thromb Haemost. 2005; 3:796-797.

54. Kashiwagi T, Matsushita T, Ito Y, Hirashima K, Sanda N, Fujimori Y, Yamada T, Okumura K, Takagi A, Murate T, Katsumi A, Takamatsu J, Yamamoto K, Naoe T, Kojima T. L1503R is a member of group I mutation and has dominantnegative effect on secretion of full-length VWF multimers: an analysis of two patients with type $2 \mathrm{~A}$ von Willebrand disease. Haemophilia 2008; 14:556-563.
55. James PD, and Lillicrap D. The role of Molecular Genetics in Diagnosing von Willebrand Disease. Semin Thromb Hemost. 2008; 34:502-508.

56. Haberichter SL, Budde U, Obser T, Schneppenheim S, Wermes C, Schneppenheim R. The mutation N528S in the von Willebrand factor (VWF) propeptide causes defective multimerization and storage of VWF. Blood 2010; 115:4580-4587.

57. Hassenpflug WA, Budde U, Obser T, Angerhaus D, Drewke E, Schneppenheim S, Schneppenheim R. Impact of mutations in the von Willebrand factor A2 domain on ADAMTS13-dependent proteolysis. Blood 2006; 107:23392345.

58. Michiels JJ, van Vliet HH. Dominant von Willebrand disease type $2 \mathrm{~A}$ groups I and II due to missense mutations in the $\mathrm{A} 2$ domain of the von Willebrand factor gene: diagnosis and management. Acta Haematol 2009; 121:154-166.

59. Rayes J, Hollestelle MJ, Legendre P, Marx I, de Groot PG, Christophe OD, Lenting PJ, Denis CV. Mutation and ADAMTS13-dependent modulation of disease severity in a mouse model for von Willebrand disease type 2B. Blood 2010; 115:4870-4877.

60. Ruggeri ZM, Pareti FI, Mannucci PM, Ciavarella N, Zimmerman TS. Heightened interaction between platelets and factor VIII/von Willebrand factor in a new subtype of von Willebrand's disease. N Engl J Med 1980; 302:10471051.

61. Holmberg L, Nilsson IM, Borge L, Gunnarsson M, Sjörin E. Platelet aggregation induced by 1-desamino-8-D-arginine vasopressin (DDAVP) in Type IIB von Willebrand's disease. N Engl J Med 1983; 309:816-821.

62. Nurden P, Debili N, Vainchenker W, Bobe R, Bredoux R, Corvazier E, Combrie R, Fressinaud E, Meyer D, Nurden AT, Enouf J. Impaired megakaryocytopoiesis in type 2B von Willebrand disease with severe thrombocytopenia. Blood 2006; 108:2587-2595.

63. Saba HI, Saba SR, Dent J, Ruggeri ZM, Zimmerman TS. Type IIB Tampa: A variant of von Willebrand disease with chronic thrombocytopenia, circulating platelet aggregates, and spontaneous platelet aggregation. Blood 1985; 66:282286.

64. Rick ME, Williams SB, Sacher RA, Mckeown LP. Thrombocytopenia associated with pregnancy in a patient with type IIB von Willebrand's disease. Blood 1987; 69:786789.

65. Hultin MB, Sussman II. Postoperative thrombocytopenia in type IIB von Willebrand disease. Am J Hematol 1990; 33:64-68

66. Federici AB, Mannucci PM, Castaman G, Baronciani L, Bucciarelli P, Canciani MT, Pecci A, Lenting PJ, De Groot PG. Clinical and molecular predictors of thrombocytopenia and risk of bleeding in patients with von Willebrand disease type 2B: A cohort study of 67 patients. Blood 2009; 113:526-534. 
67. Golder M, Pruss CM, Hegadorn C, Mewburn J, Laverty K, Sponagle K, Lillicrap D. Mutation-specific hemostatic variability in mice expressing common type $2 \mathrm{~B}$ von Willebrand disease substitutions. Blood 2010; 115:48624869.

68. Ozeki M, Kunishima S, Kasahara K, Funato M, Teramoto T, Kaneko H, Fukao T, Kondo N. A family having type 2B von Willebrand disease with an R1306W mutation: Severe thrombocytopenia leads to the normalization of high molecular weight multimers. Thromb Res 2010; 125:e17e22.

69. James PD, Notley C, Hegadorn C, Poon MC, Walker I, Rapson D, Lillicrap D. Association of Hemophilia Clinic Directors of Canada. Challenges in defining type $2 \mathrm{M}$ von Willebrand disease: results from a Canadian cohort study. J Thromb Haemost 2007; 5:1914-1922.

70. Ribba AS, Loisel I, Lavergne JM, Juhan-Vague I, Obert B, Cherel G, Meyer D, Girma JP. Ser968Thr mutation within the A3 domain of von Willebrand factor (VWF) in two related patients leads to a defective binding of VWF to collagen. Thromb Haemost 2001; 86:848-854.

71. Riddell AF, Gomez K, Millar CM, Mellars G, Gill S, Brown SA, Sutherland M, Laffan MA, McKinnon TA. Characterization of W1745C and S1783A: 2 novel mutations causing defective collagen binding in the A3 domain of von Willebrand factor. Blood 2009; 114:3489-3496.

72. Mazurier C, Dieval J, Jorieux S, Delobel J, Goudemand M. A new von Willebrand factor (vWF) defect in a patient with factor VIII (FVIII) deficiency but with normal levels and multimeric patterns of both plasma and platelet vWF. Characterization of abnormal vWF/FVIII interaction. Blood 1990; 75:20-26.

73. Nishino M, Girma JP, Rothschild C, Fressinaud E, Meyer D. New variant of von Willebrand disease with defective binding to factor VIII. Blood 1989; 74:1591-1599.

74. Hilbert L, Nurden P, Caron C, Nurden AT, Goudemand J, Meyer D, Fressinaud E, Mazurier C. INSERM Network on Molecular Abnormalities in von Willebrand Disease. Type $2 \mathrm{~N}$ von Willebrand disease due to compound heterozygosity for R854Q and a novel R763G mutation at the cleavage site of von Willebrand factor propeptide. Thromb Haemost. 2006; 96:290-294.

75. Foster PA, Fulcher CA, Marti T, Titani K, Zimmerman TS. A major factor VIII binding domain resides within the aminoterminal 272 amino acid residues of von Willebrand factor. J Biol Chem 1987; 262:8443-8446.

76. Hilbert L, Jorieux S, Proulle V, Favier R, Goudemand J, Parquet A, Meyer D, Fressinaud E, Mazurier C. Two novel mutations, Q1053H and C1060R, located in the D3 domain of von Willebrand factor, are responsible for decreased FVIII-binding capacity. Br J Haematol 2003; 120:627-632.
77. Hilbert L, D'Oiron R, Fressinaud E, Meyer D, Mazurier C; INSERM Network on Molecular Abnormalities in von Willebrand Disease. First identification and expression of a type $2 \mathrm{~N}$ von Willebrand disease mutation (E1078K) located in exon 25 of von Willebrand factor gene. J Thromb Haemost 2004; 2:2271-2273.

78. Mazurier C, Goudemand J, Hilbert L, Caron C, Fressinaud $\mathrm{E}$, Meyer D. Type $2 \mathrm{~N}$ von Willebrand disease: clinical manifestations, pathophysiology, laboratory diagnosis and molecular biology. Best Pract Res Clin Haematol 2001; 14:337-347.

79. Collins PW, Cumming AM, Goodeve AC, Lillicrap D. Type 1 von Willebrand disease: application of emerging data to clinical practice. Haemophilia 2008; 14:685-696.

80. Goodeve A, Eikenboom J, Castaman G, Rodeghiero F, Federici AB, Batlle J, Meyer D, Mazurier C, Goudemand J, Schneppenheim R, Budde U, Ingerslev J, Habart D, Vorlova Z, Holmberg L, Lethagen S, Pasi J, Hill F, Hashemi Soteh M, Baronciani L, Hallden C, Guilliatt A, Lester W, Peake I. Phenotype and genotype of a cohort of families historically diagnosed with type 1 von Willebrand disease in the European study, Molecular and Clinical Markers for the Diagnosis and Management of Type 1 von Willebrand Disease (MCMDM-1VWD). Blood. 2007; 109:112-121.

81. James PD, Notley C, Hegadorn C, Leggo J, Tuttle A, Tinlin S, Brown C, Andrews C, Labelle A, Chirinian Y, O'Brien L, Othman M, Rivard G, Rapson D, Hough C, Lillicrap D. The mutational spectrum of type 1 von Willebrand disease: Results from a Canadian cohort study. Blood. 2007; 109:145-154.

82. Cumming A, Grundy P, Keeney S, Lester W, Enayat S, Guilliatt A, Bowen D, Pasi J, Keeling D, Hill F, Bolton-Maggs PH, Hay C, Collins P; UK Haemophilia Centre Doctors' Organisation. An investigation of the von Willebrand factor genotype in UK patients diagnosed to have type 1 von Willebrand disease. Thromb Haemost 2006; 96:630-641.

83. Eikenboom JC, Matsushita T, Reitsma PH, Tuley EA, Castaman G, Briët E, Sadler JE. Dominant type 1 von Willebrand disease caused by mutated cysteine residues in the D3 domain of von Willebrand factor. Blood 1996; 88:2433-2441.

84. Bodó I, Katsumi A, Tuley EA, Eikenboom JC, Dong Z, Sadler JE. Type 1 von Willebrand disease mutation Cys1149Arg causes intracellular retention and degradation of heterodimers: A possible general mechanism for dominant mutations of oligomeric proteins. Blood 2001; 98:29732979. 
85. Eikenboom J, Hilbert L, Ribba AS, Hommais A, Habart D, Messenger S, Al-Buhairan A, Guilliatt A, Lester W, Mazurier C, Meyer D, Fressinaud E, Budde U, Will K, Schneppenheim R, Obser T, Marggraf O, Eckert E, Castaman G, Rodeghiero F, Federici AB, Batlle J, Goudemand J, Ingerslev J, Lethagen S, Hill F, Peake I, Goodeve A. Expression of 14 von Willebrand factor mutations identified in patients with type 1 von Willebrand disease from MCMDM-1VWD study. J Thromb Haemost 2009; 7:1304-1312.

86. Casonato A, Pontara E, Sartorello F, Cattini MG, Sartori MT, Padrini R, Girolami A. Reduced von Willebrand factor survival in type Vicenza von Willebrand disease. Blood 2002; 99:180-184.

87. Haberichter SL, Balistreri M, Christopherson P, Morateck P, Gavazova S, Bellissimo DB, Manco-Johnson MJ, Gill JC, Montgomery RR. Assay of the von Willebrand factor (VWF) propeptide to identify patients with type 1 von Willebrand disease with decreased VWF survival. Blood 2006; 108:3344-3351.

88. Castaman G, Tosetto A, Rodeghiero F. Reduced von Willebrand factor Survival in von Willebrand disease: pathophysiologic and clinical relevance. J Thromb Haemost 2009; 7:71-74.

89. Bowen DJ, Collins PW. An amino acid polymorphism in von Willebrand factor correlates with increased susceptibility to proteolysis by ADAMTS13. Blood 2004; 103:941-947.

90. O'Brien LA, James PD, Othman M, Berber E, Cameron C, Notley CR, Hegadorn CA, Sutherland JJ, Hough C, Rivard GE, O'Shaunessey D, Lillicrap D; Association of Hemophilia Clinic Directors of Canada. Founder von Willebrand factor haplotype associated with type 1 von Willebrand disease. Blood 2003; 102:549-557.
91. Davies JA, Collins PW, Hathaway LS, Bowen DJ. Von Willebrand factor: evidence for variable clearance in vivo according to Y/C1584 phenotype and ABO blood group. J Thromb Haemost 2008; 6:97-103.

92. Davies JA, Collins PW, Hathaway LS, Bowen DJ. The effect of von Willebrand factor Y/C1584 on in vivo protein level and function, and interaction with $\mathrm{ABO}$ blood group. Blood 2007; 109:2840-2846.

93. Castaman G, Rodeghiero F, Manucci PM. The elusive pathogenesis of von Willebrand disease Vicenza. Blood 2002; 99:4243-4245.

94. Lester W, Guilliatt A, Grundy P, Enayat S, Millar C, Hill F, Cumming T, Collins P. Is VWF R924Q a benign polymorphism, a marker of a null allele or a factor VIIIbinding defect? The debate continues with results from the UKHCDO vWD study. Thromb Haemost 2008; 100:716718.

95. Berber E, James PD, Hough C, Lillicrap D. An assessment of the pathogenic significance of the R924Q von Willebrand factor substitution. J Thromb Haemost 2009; 7:1672-1679.

96. Keeney S, Bowen D, Cumming A, Enayat S, Goodeve A, Hill M. The molecular analysis of von Willebrand disease: A guideline from the UK Haemophilia Centre Doctors' Organisation Haemophilia Genetics Laboratory Network. Haemophilia. 2008; 14:1099-1111.

97. Peake IR, Goodeve AC. Genetic testing for von Willebrand disease: The case for. J Thromb Haemost 2010; 8:13-16.

98. Flavaloro EJ. Rethinking the diagnosis of von Willebrand disease. Thromb Res 2011; 127:S17-S21. 